\title{
Financialization and Value Based Control: Lessons from the Australian Mining Supply Chain
}

\section{Rachel Parker, Stephen Cox, Paul Thompson. To be published in Journal of Economic Geography}

Accepted for publication in Economic Geography published by Taylor and Francis. The published version is available at: $\underline{\text { https://doi.org/10.1080/00130095.2017.1330118 }}$

\begin{abstract}
Lead firms operate on multiple scales and while their corporate functions may be globally organized, they are anchored in various territories through the formation of relations with local suppliers, some of whom have specialized knowledge, capabilities or technologies that are essential to the lead firms' business activities. Global value chain and global production network analysis have recognized that financialization is increasingly driving the way in which lead firms coordinate their relationships with supplier firms. The contribution of this paper is to unpack the mechanisms that lead firms adopt to govern their supply chains in the context of financialization and the implications this has for the territorial embeddedness of lead firms. The boom-bust cycle of mining, arising from massive fluctuations in global commodity prices, provides a revealing context within which to explore the changing agendas of financial markets and their implications for lead firm connections to territory. This paper examines the mechanisms lead firms use to coordinate relations with local suppliers in the Queensland coal industry, which accounts for fifty percent of international trade in metallurgical coal and which has evolved in the context of the most recent boom bust cycle of global coal prices.
\end{abstract}


Lead firms in global markets operate on multiple scales and while their corporate functions may be globally organized, they are 'anchored' in various places and regions through the formation of relations with local suppliers, some of whom have specialized knowledge, capabilities or technologies that are essential to the lead firms' business activities (Henderson et al. 2002; Hess 2004). The nature of connections between lead firms and local suppliers is influenced by lead firms' response to the dynamics of the broader global political economy (Baud and Durand 2012). Global value chain (GVC) and global production network (GPN) analysis have recognized that financialization is increasingly driving the way in which local supplier firms are articulated into the global economy through relations with lead firms (Coe, Lai, and Wójcik 2014; Milberg 2009; Ponte and Gibbon 2005).

The financialization of accumulation, in which profit is increasingly generated through financial channels (Arrighi 1994; Krippner 2005), impacts on non-financial firms such that corporate governance reflects the logics of financial markets, which define value in particular ways. In this context, shareholder value has become a driving influence on the organization of global production (Lazonick and O’Sullivan 2000; Montalban and Sakinç 2013). The logic of shareholder value dictates that corporations should be run, first and foremost in the interests of shareholders. Lazonick and O'Sullivan (2000) have documented the consequences of the rise of shareholder value with reference to the shift from the dominant corporate strategy of 'retain and invest' prior to the 1980s to the 'downsize and distribute' logic that followed from the 1980s. The effects of this logic in particular industries, such as pharmaceuticals, is well documented: 'corporate managers are increasingly constrained by institutional shareholders to prioritize maximization of stock prices and returns on equity .... (resulting in) the outsourcing of business activities to decrease the capital employed for the same profit and refocus the firm on the most profitable activities to capture rents and increase ROE...” (Montalban and Sakinç 2013, 983). 
Outsourcing and offshoring creates intensified competition in supply chains, which combined with lead firm control of strategic assets at profitable points of the supply chain, enhances the power of global lead firms to extract price concessions from their suppliers in order to pursue the value logics associated with financialization (Milberg and Winkler 2013).

The contribution of this paper is to unpack the coordination mechanisms that lead firms adopt to govern their supply chains in the context of financialization and the implications this has for lead firms' connection with place or territorial embeddedness (Henderson et al. 2002; Hess 2004). Lead firms acquire their influence through industrial position or market power in the form of either revenue or market share (Coe and Yeung 2015, 40) and they establish and enforce the conditions under which key economic actors, including their suppliers, engage with the global economy (Humphrey and Schmitz 2002). Lead firms coordinate their supply chains by nominating the products that should be produced, at what prices and how they should be delivered. This paper contributes to the increasing recognition in GVC and GPN approaches that financialization is a significant influence on lead firm governance of supply chains and relations with suppliers (Baud and Durand 2012; Coe, Lai, and Wójcik 2014; Milberg 2009; Ponte and Gibbon 2005).

The mining industry provides an ideal context in which to examine the effects of lead firm financialization on the anchoring of lead firms in local places through the processes of local supply chain coordination. The landed nature of extractive industries and their geological characteristics would suggest that lead resource firms would be strongly anchored in local territories and would experience a high level of territorial embeddedness (Morris, Kaplinsky, and Kaplan 2012). At the same time, the resource industry is deeply financialized arising from heavy dependence on equity finance to support high risk mineral exploration and capital intensive extraction and processing. The boom-bust cycle of mining, arising from massive fluctuations in global commodity prices, provides a context in which to explore the 
changing agendas of financial markets and their implications for lead firm connections to territory. These dynamics are examined in the context of the Queensland coal industry, which accounts for fifty percent of international trade in metallurgical coal (used in steel production) and which has evolved in the context of the boom bust cycle of global coal prices over the last ten years (Geological Survey of Queensland 2016).

The following section of the paper reviews existing global value chain and global production network literature explaining the impact of financialization on lead firm territoriality and coordination of supply chains. The subsequent section draws on the financialization literature to unpack the territorial implications of changing lead firm procurement approaches including the increased emphasis on value based management and cost minimization. The third section explores these issues in the context of the global mining industry and in the specific case of the Queensland mining industry. The fourth section outlines the research methods. The subsequent sections explain the way in which financialization is driving a de-territorialization of lead firms in the Queensland mining industry. The paper concludes with a discussion of future research directions for economic geographers in relation to this work.

\section{The Impact of Financialization on Lead Firm Coordination of Production and Territorial Embeddedness}

Financialization is the process by which non-financial firms are driven by the logics of capital markets in which they seek to maximize the attractiveness of firm shares to investors. Investor interest is sustained by maximizing firm performance in relation to the predictive models of financial analysts regarding future share value (Nölke and Perry 2007; Williams 2000). Shareholder capitalism drives firms to increase the return on capital 
employed (ROCE) and thereby maintain or increase dividend payments, or shareholder income stream, which results in positive investor assessment of investor return. Share buybacks are a further instrument for maximizing shareholder value because buy-backs result in a reduced volume of publicly traded shares resulting in an increase in the earnings of retained shares. Disinvestment of less profitable or low yielding parts of business is also used to maximize shareholder value (Montalban and Sakinç 2013, 984; Ponte and Gibbon 2005). Firms use divestiture to extract profits and increase dividends and repurchase stocks (Montalban and Sakinç, 2013, 984). Investors tend to focus on the intrinsic value of stock, as measured by financial analysts' assessments of future firm performance, which heavily weights cash returns. There is therefore an increasing tendency for firms to deliver on the financial analysts' assessment criteria by reducing costs because in many industries, price competition has eliminated the capacity to generate profit through price increases (Milberg 2009).

Financialization has important implications for territoriality of lead firms, or the way in which lead firms organize their global production activities. First, off-shoring, or the globalization of supply chains, has facilitated the concentration of economic assets in lead firms by expanding their revenue base, which has enabled them to secure additional strategic assets including technology, human resources, forms of production organization, intellectual property and marketing and design, which form barriers to entry for competitor firms. These strategic assets underpin "super profits premised on the existence of barriers to entry" (Kaplinsky 2004, 7). Only globalized financialized firms, with high market capitalization, have the resources to secure these strategic assets. Lead firms are "those that drive global production networks and make things happen. Their ability to do so depends on their asymmetric control and internalization of key resources" (Coe and Yeung 2015, 65). The global reorganization of production has been critical for lead firms to secure strategic assets 
and positions of market power that enable them to deliver shareholder value and sustain investor interest. The processes of financialization and globalization are therefore intimately entwined (Baud and Durand 2012).

Second, globalization has enabled lead firms to increase competition within supply chains through global sourcing across multiple territories. The resulting competitive pressures amongst suppliers has enabled lead firms to drive cost reductions along their supply chain. Essentially, lead firms have derived operational advantages, including reduced input costs, at the expense of supply chain firms, because of their increased market power arising from globalization (Baud and Durand 2012; Montalban and Sakinç 2013). Milberg and Winkler (2013) show that the management of GPNs has been a critical component of corporate strategy to capture rents from oligopolistic power. Offshoring of production activities has therefore resulted in forms of economic organization in global production networks characterized by oligopolistic lead firms and highly fragmented and competitive supplier networks. Asymmetrical market structures and associated practices of off-shoring have enabled US firms to increase their mark-up and profit share (Milberg and Winkler 2013). Lead firms utilize offshoring as an instrument for cost reduction creating new sources of profits, which enable them to deliver on financial market imperatives.

The effect of these trends is demonstrated by Foster and McChesney (2012). Large multinational firms have diversified across nations and industry sectors, such that the concentration (through capital accumulation) and centralization (through mergers and acquisitions) of economic activity far exceeds that which prevailed in the immediate postWorld War II era. The total gross profit share of the top two hundred US Corporations as a percentage of total business profits in the US economy more than doubled between 1950 and the mid-2000s (Foster and McChesney 2012, 71). As Foster and McChesney (2012) argue, "the capacity of the giant firms in the economy to obtain higher profits than their smaller 
competitors is the main indicator of the degree of monopoly exercised by these mega corporations" (p. 71). Vitali, Glattfelder, and Battison (2011) have shown that a core group of 147 MNCs control almost 40 percent of the economic value of the world's population of MNCs (cited in Coe et al. 2014, 765).

The effects of the changing nature of lead firm territoriality and coordination of supply chains in the context of financialization is further explained by Mahutga (2014), who shows that lead firms in sectors such as apparel establish massive advertising budgets to sustain brand power, which creates barriers to entry and enables high levels of concentration amongst buyers. Only large MNCs with significant capital to invest in developing and maintaining brand image are able to secure a position in the highly profitable buyer nodes within global retain chains. Buyers are able to exert downward pressure on price in negotiations with the large number of competing suppliers who have relatively few alternatives. In producer-driven chains such as transport equipment, the main resources of lead firms are "highly capitalized and technologically advanced production facilities as well as knowledge and technology intensive R\&D operations", which create barriers to entry at the production point of the GVC and enable producers to put downward pressure on price in their transactions with suppliers (p. 166).

Financialization drives lead firms to maximize returns on equity and distribute value to shareholders. Globalization has been an essential strategy for lead firms to reduce their direct involvement in production through increased outsourcing and to decrease their input costs by increasing global competition along their supply chains. "Such reorganization frees up financial resources to increase share buybacks and dividends in order to satisfy shareholders" (Baud and Durand 2012, 241). The resulting profits are used to meet the demands of shareholder value (Milberg and Winkler 2013). Financialization is therefore 
affecting the organization of global production and the territorial dimensions of lead firm strategy.

\section{The Mechanisms of Coordination and their Territorial Implications}

Financialization is influencing the ways in which lead firms establish the conditions under which suppliers participate in global markets (Gibbon 2002). Procurement arrangements have become a key mechanism for lead firms to coordinate their supply chains to deliver the demands of shareholder value creation. Procurement is the process of vetting or selecting suppliers of good and services, which might involve competitive bidding between suppliers, the establishment of the principles under which supply will operate (including payment terms and delivery times) and the negotiation of contracts for the purchase of goods and services. Building on Cushen and Thompson (2016), the following discussion elaborates on the way in which financialization is affecting procurement arrangements, through the growing emphasis on value based management and cost minimization, and the implications this has for the territorial embeddedness of lead firms.

\section{Value Based Management}

Financialization influences the behavior of lead firms in global markets by encouraging the adoption of value based management approaches that utilize formalistic metric based calculations in management decision making. This affects global suppliers by driving standards and evaluation criteria in procurement processes. Financialization has led to strengthened forms of value based control in procurement arrangements, which are necessary to meet the demands of metrics driven ratings agencies and investment intermediaries. 
"Value based management (VBM) refers to tools that financial managers can use to plan, monitor, and control a firm's operations in ways that enhance shareholder value" (Martin and Petty 2001) leading to the adoption of financial models of evaluation and control both within the firm and in relations within supply chains. Accounting standards promote a form of value based calculation in firm decision making that elevates quantitative and formalistic metrics over strategic decision making (or longer term market positioning). Metrics, scoreboards and rankings underpin a logic of formal rationality in engagement with suppliers, focused not on end goals, but on mechanistic evaluation of closed criteria (Froud et al. 2000).

These conventions or norms for measuring and evaluating value are established through international accounting standards. While previously accounting practice utilized a historical cost accounting approach in assessing value, in which an asset value was gauged relative to its purchase price, accounting standards have shifted to focus on what is described as 'fair-value accounting' (Nölke and Perry 2007) in which an asset's performance is defined with reference to expected future income streams or "in other words, simulating what a rational market participant would do" (Perry and Nölke 2006). These market participants are the credit rating agencies and intermediaries that control large investment funds, pensions and the investment divisions of international banks who have been given an elevated influence over managerial decision making through the adoption of these new accounting codes.

Value based management is designed to ensure the adoption of these standards as key decision making influences within the firm. Consultancy firms that sell their shareholder value creation products to corporate managers, emphasize the importance of implementation and incentive packages that ensure that value becomes a universal language across all corporate functions (Froud et al. 2000), including and essentially within procurement divisions that manage supply chain relations. 


\section{Cost Minimization}

Financialization has also resulted in an emphasis on cost minimization in procurement, which has been an important mechanism for lead firms to capture rents from their control of strategic assets, which is necessary to deliver on the demand of financial markets to maximize shareholder return. The prioritization of cost minimization is being achieved through outsourcing and offshoring, which enhance competition in the supply base and enable lead firms to exert downward pressure on costs through global procurement of products and services (Baud and Durand 2012; Milberg 2009).

Milberg (2009) shows that import price deflation is a characteristic of highly developed global value chains in which there are high levels of offshoring and supplier competition, documenting import price declines of a magnitude of 40 percent in the 20 years up to 2006 in clothing, footwear, textiles, furniture, chemicals. Essentially, these are highly saturated product markets in which lead firms occupy oligopolistic power. "From the leadfirm perspective, excess capacity and the steady arrival of new entrants in supplier markets serve the purpose both of cost reduction and of greater flexibility" (with the possibility of multiple suppliers facilitated by globalization) (Milberg 2009, 433).

Baud and Durand $(2012,14)$ explain the increasing returns on equity in the retail sector at a time of declining domestic market growth with reference to the success of retailers in sustaining market ups through cost reductions imposed on workers and suppliers through global procurement arrangements. The adoption of IT systems and logistics arrangements enables retailers to better monitor and control the supply chain through procurement processes. Suppliers have had to increase their volume and pace of delivery in order to secure their continuing position in the global supply network.

\section{Territorial Embeddedness}


Procurement has become a mechanism for lead firms to shape access to global markets in ways that prioritize the agenda of shareholder value - by implementing the logic of value based management through the establishment of a limited range of metrics based criteria that emphasize cost minimization. The relationship between lead firms and local suppliers, and in particular their territorial embeddedness, or extent to which lead firms depend on local suppliers, would appear to be related to the forms of coordination adopted by lead firms in the context of the broader dynamics of the global production network, including financialization.

Territorial embeddedness refers to the extent to which lead firms are committed to or 'anchored' in specific territories or places (Hess 2004). Lead firms are heavily embedded in particular regional locations when they become intensely reliant on or constrained by the institutional, social or economic characteristics of the region, for example by forming dependent relations with local suppliers who provide unique and difficult to access resources to the lead firms. In this way, local firms articulate into global markets through their relations with lead firms and benefit from access to global market opportunities (Amin and Thrift 1994; Ernst and Kim 2002; Humphrey and Schmitz 2002).

When the ability to codify information exchanged in an economic transaction is low, lead firms have relied on forms of coordination that involve high levels of territorial embeddedness. Trust based social relations have been the necessary mechanism to avoid the opportunistic behaviors that are possible when transactions involve the exchange of complex design information, non-standard inputs and integrated product design architectures (Sturgeon 2009). Geographically co-located buyers and highly competent suppliers engage in sustained relationships underpinned by trust, reputation and tacit knowledge exchange, such as those identified in segments of the fresh produce and apparel chains (Gereffi, Humphrey, and Sturgeon 2005). Territorially embedded firms rely on coordination through reputation 
and social relations as Uzzi's analysis of the New York garment industry illustrates (Uzzi 1997), suggesting that local relations and face to face knowledge exchange are likely to be involved in this form of coordination. This approach adopts a highly territorialized conception of embeddedness (Amin and Thrift 1994) in which proximity is attributed a significant role in creating trust amongst economic partners (Hess 2004).

However, financialization incentivizes lead firms to develop 'hands-off' forms of coordination, which enable them to prioritize shareholder value and which result in the deterritorialization of lead firms. Codification, through the development of standards or conventions, such as those associated with value based management, facilitates a global approach to sourcing, which does not require lead firms to be anchored in particular territories, thereby enabling lead firms to rupture relations with local suppliers (Ponte and Gibbon 2005).

This allows lead firms to develop what Ponte and Gibbon (2005) have described as 'arms-length' or 'hands-off' coordination of supply chain relations. 'Hands-off' coordination of supply chains involves an outsourcing of non-core functions, emphasis on short-term returns in supplier relations, 'playing' with the possibility of switching partners by establishing competitive tendering processes and creating competition within the supply base to gain status as 'preferred supplier' (Ponte and Gibbon 2005, 20). 'Hands-off' forms of coordination break down the connection between lead firms and place associated with deeper and longer term relations with trusted suppliers.

\section{The Impact of Financialization on Lead Firm Coordination of Production and Territorial Embeddedness in the Global Mining Industry}

The financialization and globalization of the mining industry have impacted on the way in which mining firms coordinate their supply chains and the extent to which lead firms 
form close relations with specialized suppliers in local places. The materiality of mining (and other resource extraction industries) arises from the 'landed' nature of extractive assets suggesting a particularly local and place based nature of production. Geology, or variations in resource quality (the ease of access and quality of ore bodies), implies that the global distribution of mining activity will be determined by nature rather than strategic or organizational intention (Bridge 2009). It might also be expected that lead firms in the resources industry would coordinate their supply chains through close relations with local suppliers, given that the nature, quality and location of bedrock varies by site and requires specialist local expertise or equipment in extraction and processing (Morris, Kaplinsky, and Kaplan 2012). However, in mining enclaves, lead firms establish weak productive linkages with the local economy, rely heavily on suppliers outside the local region, and contribute little to the development of productive activities beyond narrow paths of industrialization (Arias, Atienza, and Cademartori 2014; Phelps, Atienza, and Arias 2015).

The way in which local firms are articulated into global production networks is impacted by the extent of globalization and financialization of the mining industry which have led to a heavy concentration of economic assets. As firms in mining and metals are capital intensive, they have depended on equity markets to support high risk exploration and mineral project development and this has led to a concentration of capital at the mining exploitation stage of the global value chain.

An indication of the growing financialization and globalization of the mining and metals industry, market capitalization had reached record levels by 2010 . The minimum market capitalization of the top 40 firms in 2010 was US11bn, significantly higher than the \$6.5bn required to enter the top 40 in 2009 (PWC 2011). In addition to the substantial growth in the stock value of the top forty, there was also considerable concentration in the industry globally. BHP Billiton, Vale and Rio Tinto market capitalization was significantly higher 
than other global miners. Rio Tinto, the smallest of the top three, had a market capitalization twice the level of China's Shenhua which sat at fourth place. The top three companies by revenue represented $36 \%$ of total revenues of the top 40 global miners in 2010 (PWC 2011).

Although geology plays an important part in the place based distribution of mining production and lead firm relations with suppliers, global competition between resource endowed regions has intensified from the 1990s as more nations sought to attract foreign investment through market liberalization and clarification of principles of land tenure. The globalization of mining production is demonstrated by the shifting partners of global investment activity. The share of mining investment in North American and Australasia declined by half to $25 \%$ of worldwide flows in 2000 , from a starting point of $50 \%$ of worldwide flows at the beginning of the 1990s (Bridge 2004). Lead firms have significantly expanded their regional investment options during this period. In addition, the boom bust cycle of commodity prices renders production a function of global market conditions and not just geological possibilities. As with other industries, the globalization of mining production has resulted in intensified competition between mining regions and in the supply chain (Bridge 2004).

\section{Methods}

This paper is focused on the case of the Queensland mining industry which accounts for 7.3 percent of gross product and fifty-nine percent of the State's exports. Coal is a particularly important commodity. Queensland accounts for fifty percent of international trade and one eighth of global production in metallurgical coal (coking coal used in iron and steel making) and fifteen percent of internationally traded thermal coal (used in energy production). Coal production taking place in 2015 occurred in 41 open-cut and 13 
underground mines. After coal, base metals are the most significant sector in Queensland's mining industry including bauxite, copper, gold, zinc, lead, silver (Geological Survey of Queensland 2016).

The mining equipment, technology and services sector are the major group of local supplier firms that form relations in upstream mining with the lead firms. As METS firms' activities do not map on to standard industry classifications, no national representation of the sector size, composition and activities is available. Austmine, the major national industry association representing the METS sector, has reported that there are around 149 METS firms in Queensland for whom mining firms are their major customers and eighty-five percent of these firms have some involvement in coal. The bulk of these firms (85.9 percent) are majority Australian owned. While just over fifty percent of METS firms in Queensland are involved in exporting, very few earn more than twenty percent of their revenue from exports and are instead very heavily dependent on relations with local lead firms (Austmine 2013).

We utilized two main data sources for this research. The first was the major financial newspaper in Australia, the Australian Financial Review (AFR), which reports market trends. The AFR was used as an information resource on corporate activity and market trends and was searched through the digital database Factiva. Other publicly available resources produced by major consultancy organizations that track mining industry trends and public institutions such as the Australian Securities Exchange and the Reserve Bank of Australia were also utilized and are cited below. The information obtained from these sources was used to track major corporate developments and obtain data on industry concentration and capitalization.

The second source of data was thirty-seven semi-structured interviews in Brisbane, Queensland. Thirty-four interviews were conducted with firm managers of firms of a variety of different sizes for whom the mining industry is their major customer or sector of operation. 
Of the thirty-four firm interviews, one was with a mining industry investment firm, four were with the $\mathrm{CEO} / \mathrm{CFO}$ or procurement manager of mining firms and two were with procurement managers from Engineering, Procurement and Construction Management (EPCM) firms. The remaining twenty-seven interviews were conducted with supplier firms in the mining and engineering technology sector (METS). In addition to the thirty-four firm interviews, three interviews were conducted with industry experts: one from a mining focused research institution with investment experience and two from government.

Interview questions focused on the nature of the relationships between Australian METS firms and their customers, how firms 'win work' locally and globally, how firms negotiate to capture revenue for their product/service, firm capabilities and technologies, and the competitive strengths and weaknesses of the METS sector. Once we achieved a high convergence of responses we ceased interviews (Corbin and Strauss 1990). Interviews were coded thematically (Corbin and Strauss 1990; Glaser and Strauss 1967). This paper focuses on themes that emerged from the data around cost minimization and value based logics in procurement processes.

\section{Financialization in the Queensland Mining Industry}

The Queensland mining industry reflects the broader trends associated with financialization and globalization of production. The lead firms in Queensland's mining industry have always been global multinational corporations. The Queensland coal industry, which is at the core of Queensland mining, developed in the 1950s and 1906s, primarily through the activities of the USA firm, Utah Construction Company. Between 1967 and 1972, Utah Construction Company developed four mines, a rail link and a port facility in Queensland. By 1981, they owned a majority share in six mines and produced 50 percent of 
the state's coal production (Resource Information Unit 1984). Galligan $(1989,28)$ shows that over a twenty year period between 1965 and 1985, Utah produced sixty six percent of Queensland coal exports (Galligan 1989, 28).

Although Utah was a global company whose American shareholders massively benefited from the 1970s growth of the Japanese economy and the OPEC oil crisis, Queensland was a central component of Utah's global business, accounting for ninety percent of the firm's profits throughout the 1970s. As a result, Utah was heavily embedded in Queensland as a place, many of its employees had been with the firm for a 'professional lifetime' and significant autonomy rested with the local Australian managers of Utah operations who built close relations with the engineering professional community. In addition, the profits generated by Utah throughout the 1970s followed two decades in which the Australian operations of Utah operated at a small loss, suggesting the company did not adopt a short-term orientation in its connection to Queensland based mining operations (Galligan 1989).

By 1981, Queensland had around 25 operating coal mines. Utah had a majority share of six mines and produced 50 percent of the State's coal. The second largest firm was BHP Minerals with a majority share in 4 mines. In 1984, the Australian listed company BHP acquired Utah Development. The acquisition of Utah by BHP provided BHP with access to Utah's portfolio of global assets and was a central component of BHPs strategy to transition from 'the Big Australian' to a 'major world minerals player' (Marcus 2000, 16D). BHP's transition in the 1980s coincided with broader global processes of internationalization of production and financialization depicted above (Milberg and Winkler 2013). At that point, BHP became a truly global company as it extended BHP's operations into the USA, Brazil, Canada and Chile. The financialization of BHP follows the pattern of financialization of other major global corporations from the 1980s (Lazonick and Mazzucato 2013). 
At the same time, between 1980 and 2010, the volume of coal production in Queensland massively increased (from 34.7 Mt to 206.6 Mt). Throughout the period, coal production was heavily concentrated. By 2010, it was BHP and Rio Tinto that were engaged in the highest volume of coal production, accounting for almost half of Queensland coal production. By 2013, there were 58 coal mining operations in Queensland. BHP Billiton (in partnership with Mitsubishi Alliance and BHP Mitsui Coal) is the largest miner with 11 mining operations. Anglo American, Glencore and Rio Tinto together with BHP Billiton account for two thirds of the coal mined in the state (Resource Information Unit 2012).

The financialization and structural power of lead firms is demonstrated by their level of market capitalization. The top five companies by market capitalization account for over $75 \%$ of the market value of mining and metals firms listed on the Australian Securities Exchange (ASX) and of particular importance, BHP Billiton alone accounts for almost 50\% of the market value of the top 100 firms in the sector and BHP and Rio together account for around 60 percent of the market value of ASX top 100 firms in mining and metals (ASX, 2013).

The lead firms, the mining 'Majors', have the financial capacity to secure the highest yielding ore bodies, which are the basis of rents in commodity based industries (Morris, Kaplinsky, and Kaplan 2012), ensuring that they are positioned at the most profitable points of the value chain. Their competitors control lower yielding ore bodies that are more difficult to mine and are therefore less profitable and more vulnerable to commodity price declines.

The logics of shareholder value have been a key feature of senior management's decision making in the lead firms. The influence of shareholder value principles became particularly apparent after the commodity price collapse. From its peak at the end of 2011, the contract price for thermal coal fell by 44 percent by mid-2013. As was reported in... 
"More than 10,400 jobs have been lost in the Australian coal industry since the middle of 2012. Last week, Anglo-American boss Mark Cutifani said the outlook for the industry was 'grim'. This followed a comment by former Macarthur Coal chairman, Keith De Lacy that the industry was in crisis" (Glasgow 2013).

In 2013, Rio Tinto was put on a negative credit watch by Standard and Poors. The major financial paper in Australia, The Australian Financial Review, argued on 2 April 2013 that mining companies need to "rebuild the case for why investors should buy their shares". The financial papers and financial markets reported that the CEOs of BHP and Rio Tinto had not responded quickly enough to the changed environment in 2012 and by the beginning of 2013 they were removed from office:

"Rio Tinto chief executive Tom Albanese and BHP Billiton chief executive Marius Kloppers were removed from their jobs in January and February respectively. They were replaced by a new set of executives who wasted no time reinforcing the new paradigm: cost cuts, a reduction in capital expenditure and the sale of non-core assets to bolster the balance sheet" (Hobbs 2013).

In 2014, PWC reported that the top 40 mining companies globally (by market capitalization) had a 72 percent (or $\$ 52$ billion) fall in net profits to $\$ 20 \mathrm{bn}$, the lowest it had been for a decade (PWC 2014, 7). However:

“despite the difficult year, the industry's focus on rewarding shareholders continued during 2013. The top 40 listened to their shareholders by reigning in spending but maintaining their track record of paying dividends" (p. 13)

As a consequence, the dividend pay-out ratio (measured by dividends divided by adjusted net profits) increased from 40 percent in 2012 to 95 percent in 2013 . The dividend 
payments were highly concentrated, with the top five companies paying 50 percent of the value of total dividends paid by the top 40 companies. In order to sustain this level of dividend payments, with declining profits, companies have had to use retained earnings and in some cases debt (PWC 2014).

\section{The mechanisms by which financialization is driving the de- territorialization of lead firms in the Queensland mining industry}

Lead firms in the Queensland mining industry have established the principles under which their suppliers participate in the mining global supply chain. As the lead mining firms in Queensland continued to sustain their dividend payouts to shareholders in the competition for investor funds, they also drove financialized logics in their value chain relationships. The following discussion outlines the way in which financialization is affecting procurement arrangements adopted by lead firms in coordinating their mining supply chains, through the growing emphasis on value based management and cost minimization, and the way in which these financialized logics have worked in conjunction with the globalized nature of mining activities to rupture relations with local suppliers and the territorial embeddedness of lead firms.

\section{Value Based Management}

Value based control mechanisms have been implemented through the strengthening of procurement divisions within the lead firms and a commitment to value metrics as the basis for decision making. These are important mechanisms through which financialized value logics play out in the global production network and encourage a disarticulation of local suppliers from global productions. In order to drive financialized agendas along the value chain, lead firms are seeking to rupture relations between mine site managers and local 
suppliers by adopting centralized procurement arrangements which incorporate the normalized logics of financial markets as the basis for decision making. Through the use of the conventions of value based management (Ponte and Gibbon 2005), lead firms are able to use corporate head office to drive financialized agendas in relations with suppliers and break the deeper, longer term relations between mine site managers and local engineering and technology suppliers.

Significant resources are being invested in the struggle for control of the value chain through the employment of procurement management teams that drive hands-off formalistic decision making processes in value chain relationships. Procurement managers are typically located in central divisions of the firm and represent a different approach to engaging suppliers than would typically occur at the mine-site where mine-site managers (usually engineers) form direct and often long term relationships with suppliers. The strengthening of procurement management control over the global value chain enables the Majors to deliver on the tough value metrics designed to reduce capital expenditure and costs (see below). This is shown in the very influential role of procurement managers within the firm and in driving value chain relationships.

It is not just the Majors that are enriching procurement divisions, the practice is extending down the value chain to Tier 1 suppliers that are often responsible for procurement and operation of the Majors' mines. An Engineering Procurement and Construction Management (EPCM) firm (a Tier 1 Supplier to the Majors) reported that they are in the process of recruiting fifty procurement managers who will be 'category managers' for procurement, which "will take a lot of the responsibility away from the guys who are in the field making decisions and bring it back to a center-led team" (METS 435, 6). The aim has been to ensure that mine-site managers, typically engineers, are not able to control value chain relationships. As the procurement managers themselves report, the growing influence 
of procurement divisions is to ensure that "we will have 100 percent control over where people buy from" (METS 435, 10).

Procurement divisions, which are driving a centralization of decision making regarding which suppliers the firm engage with and on what conditions, were highly critical of the role played by mine-site managers in managing relations with suppliers. Procurement managers were dismissive of the suggestion that mine-site managers used engineering expertise and knowledge of particular mine site conditions as a basis for their decision making. Instead, procurement managers suggested that mine-site managers simply awarded work to 'their mates' (with whom they had long term relationships), whereas procurement divisions used technical, rational and objective criteria as the basis for decision making (METS 435, 8). The aim of procurement was to break the social relations that were believed to underpin the way in which mine-site engineers managed value chain relations.

The nature of the procurement process is such that in order to progress through the first stage, supplier firms need to demonstrate that they have the capability to deliver. However, once they are deemed to meet the minimum capability requirements, cost is the driver, not relative levels of capability. In this environment, METS firms find it harder to 'sell' the value of their product because its value is not captured by the limited codification achieved through the procurement framework. The process was explained in the same way by a METS firm:

"The first question is: are they technically capable of doing the job, and then that's the technical side of things taken care of so that the project engineer may be taken off - or the project manager may be taken out of the discussion at that stage and it just purely becomes a procurement exercise of - well out of these three technically capable providers who's the cheapest?" (GMETS 415, 27-28). 
At this point, the project manager (engineer) might want to recruit a supplier whom they trust and know to be flexible and capable of dealing with any changes that might develop during the project, even though their preferred supplier might cost a little more. But "procurement say no: your role in this assessment is to determine whether the company and/or its technology are capable of doing the project, yes or no?’. Once the project manager/mine site manager has deemed a supplier to be technically capable against the specifications of the activity, then the role of the mine site manager ends and their input into decision making is finished (GMETS 415, 27-28). In this way, the influence of social relations between local mine-site managers and local suppliers in the procurement process is minimized and the articulation of local suppliers into global production networks is ruptured by the formalistic criteria of procurement. The adoption of 'hands-off' coordination of the supply chain contrasts with deeper longer-term relations associated with relational forms of coordination (Gibbon, Bair, and Ponte 2008).

\section{Cost minimization}

In addition to disrupting local relations between lead firms and suppliers, the strengthening of value based management approaches in the procurement divisions of the mining Majors is designed to facilitate and enhance a global approach to supplier relations, which enables lead firms to prioritize cost minimization by intensifying global competition between suppliers. Following the commodity price collapse, in which mining Majors were no longer able to profit through commodity price increases (or revenue growth), the financialized logics shifted from increasing the numerator (revenue) to reducing the denominator (costs). Rio Tinto reported to the market that it had developed a "greater focus on value". Glyn Lawcock, UBS analyst, noted that Rio's "new mantra is value over volume" (Saunders AFR, 17-18 October 2015). In July 2014, BHP announced it would "remain focused on value over volume". 
When the main priority of the lead firms was volume, they drew heavily on close relations with local suppliers to assist them in increasing capacity to maximize extraction. During the period of high and growing coal prices, the large miners were in an investment phase of their operations and their aim was to extract coal as fast as possible. Local suppliers benefited with increased activity and prices (AIM433, 16). Following the boom, the lead firms severed relations with local suppliers and reoriented decision making towards cost reduction.

During this period, independent miners, not subject to stock market pressures, adopted a different approach. They sought to manage their business by trying to:

"keep an even keel through the good times and the bad rather than stressing the business by going up and down with the market at that time. ... keeping that even keel is linked to long-term relationships. It's linked to not screwing the contractors to death just because you can" (AIM433, 17).

In contrast to the independents, BHP Billiton and Rio Tinto have competed to become the world's lowest cost exporters to China. The intensified competition to demonstrate to investors lead firm status in terms of cost reduction has resulted in "both miners driving their costs lower" (Saunders AFR, 7 Sep 2015). The aim has been for the lead firms to ensure that they have low 'break-evens' per tonne, sitting below the existing and projected commodity prices per tonne. Factors contributing to break-evens, such as the distance of mines from the coast/ports, have been beyond the miners' control. However, “cash costs - the key component of a miner's break-even that it can control - have not been at such low levels for Rio or BHP since 2004” (Saunders AFR, 7 Sep 2015). In February 2014 - BHP announced it was aiming for an average 20 percent return rate from investments, resulting in intensified 
internal competition for capital. The 20 percent target is an increase on the 15 percent target which had prevailed 18 months earlier (Macdonald-Smith AFR, 19 Feb 2014).

As prices decline, the Majors have sought to satisfy shareholders by maintaining their earnings through control of costs and investments. This has been achieved through the imposition of restrictive ROI requirements, which displace mission oriented strategic decision making processes. Value metrics and scoreboards, rather than strategic growth oriented agendas, have driven decision making. At the same time as using value metrics to set targets for cutting capital expenditure, mining companies worked hard to slash costs through the imposition of blanket cost calculations. Rio Tinto had a cost reduction target of $\$ 2 \mathrm{bn}$ for 2013 which it exceeded by $15 \%$ while BHP Billiton had a target efficiency savings totaling \$5.5bn through 2014 (PWC 2014, 25).

The imposition of value based control through the Majors' procurement teams has played a critical role in the cost-cutting drive. As a METS CEO who had previously worked in a Major Mining firm reported:

"I think these days they are taught how to handle suppliers and they are taught to really drive the price down" (METS 402, 12).

As a METS supplier explained, procurement is not really used to select between customers; it is used to drive price down:

"So the interesting thing is 85 per cent of jobs are won by the incumbent, so the customer already knows who they're going to pretty much pick before they even go to tender. The role of procurement is to ... get a dollar saved. That's the KPI for a procurement group typically" (METS, 26). 


\section{Discussion}

Financialization involves an increasing influence of principles of shareholder value in the strategic behaviors of non-financial firms. Lead firms are thereby driven by the desire to maximize the attractiveness of firm shares to investors through share buy-backs, dividend payments and increases in the return on capital employed (Lazonick and O'Sullivan 2000). The GVC and GPN literature has shown that financialization has important territorial implications because it has been accompanied by the related process of globalization or offshoring, which has facilitated the concentration of highly valuable economic assets in lead firms, enabling lead firms to meet the demands of shareholder value while also maximizing competition in the supply base (Milberg 2009; Milberg and Winkler 2013). The resulting asymmetrical market structures allows lead firms to drive financialization agendas in their supply chains (Baud and Durand 2011, Montalban and Sakinç 2013).

Lead firms in the Queensland coal industry have always benefited from significant market power in the form of high market share and the capacity to generate rents, as explained by Kaplinsky (2004), arising from their control of strategic assets in the form of high yielding ore bodies. During the period in which Utah was the lead firm in the Queensland coal industry, significant autonomy rested with local engineers who were well connected with the local engineering professional community. After the acquisition of Utah in the mid-1980s, BHP and the other mining majors became increasingly global in their operations, in line with the opening up of mining and resources opportunities across the globe and the global fragmentation of mining production (Bridge 2004). As mining is a high capital intensity and high risk industry, there is a heavy dependence on equity financing, and lead mining firms in Queensland followed the pattern of other multinational firms in become 
increasingly financialized and subject to the discipline of shareholder value from the $1980 \mathrm{~s}$ (Milberg and Winkler 2013).

As Milberg and Winkler (2013) have argued, the coordination of value chain relationships needs to be understood in the context of the changing global production and financialization of lead firms. The changing priorities of financial markets can be observed in lead firms' relations with suppliers during the massive growth of the Queensland coal industry following the commodity price boom of the late 2000s. In the initial stages of the boom, the priority of financial markets and the lead firms was to maximize production as fast as possible to satisfy growing global demand, particularly for metallurgical coal used in steel production. Significant autonomy rested with local mine site managers, who relied heavily on local suppliers, in order to achieve a fast upscaling of extraction and processing. As volume became the main focus of corporate managers, little regard was given to cost increases, which could easily be borne with the sudden and dramatic growth in global prices for metallurgical coal. Lead firms adopted relational approaches to value chain coordination (Gereffi, Humphrey, and Sturgeon 2005), which depended on close personal relations between mine site managers and local suppliers. The commodity price spike enabled lead firms to deliver shareholder value, even in the context of rapidly rising prices within the supply chain.

Following the collapse of the coal price between 2011 and 2013, financial markets shifted their agenda to cost control. Lead firms adopted "hands off coordination" of their supply chain, involving standards for supply chain procurement that displaced relational forms of coordination (Ponte and Gibbon 2005). The intensified focus on value and global sourcing in procurement processes lead to a rupture of relations with local suppliers. The majors centralized procurement activity within the firm in order to reduce the influence of local mine site managers in the procurement process and to break down the decentralized approach, which was blamed for having driven up costs. Relations between mine site 
managers and local suppliers were disrupted by the centralized approached to procurement, which enabled the majors to draw on their corporate power and concentrated mining assets to drive cost reductions down the value chain. Mining firms faced significant downward pressure on stock value and readily responded to the demands to 'reign in costs' with significant implications for their relations with local suppliers.

In the context of the mining industry, the intensified use of centralized procurement became a key mechanism for delivering value based management agendas and cost minimization. Financialization encouraged the adoption of metric based calculation in supply chain relations in alignment with the formal rationality and mechanistic evaluation of closed criteria preferred by investors and fund managers (Froud et al. 2000; Nölke and Perry 2007). An intensified emphasis on cost minimization in supply chain relations was a further consequence of mounting financialization pressures following the boom, such that lead firms sought to impose cost reduction on suppliers in order to retain sufficient earnings to continue to deliver dividends to shareholders in the context of declining global commodity prices (Baud and Durand 2012; Ponte and Gibbon 2005).

Financialization drove hands-off coordination of supply chains following the commodity price collapse in ways that encouraged a disembedding of lead firms from local territories (Hess 2004) through the severance of local relations between mine site managers and local suppliers. However, the behavior of lead firms in the mining industry during the boom demonstrates that financialization does not inevitably drive cost minimization and hands-off value based management approaches with suppliers. In the boom time, the super profits which arose in the mining industry facilitated a decentralized approach enabling mine site managers to rapidly scale up production through the use of local suppliers and with little regard to the cost effects, which were readily absorbed by the commodity price spike. 
Financialization has territorial implications, because it affects the mechanisms lead firms adopt to coordinate their supplier networks, which in turn affects lead firms' connection with territory and the articulation and disarticulation of local suppliers from global production (Coe and Yeung 2015). While financialization appears to be broadly driving a lead firm agenda of disarticulation from place, it is not unidirectional and at least in the case of mining, with its boom bust cycle, the extent of articulation of local suppliers in global production networks appears to depend on the stage in the life of the commodity cycle.

\section{Conclusion}

The contribution of this paper has been to unpack the mechanisms lead firms adopt to coordinate their supply chains in order to satisfy the demands of investors and ratings agencies in the context of financialization and to explore the territorial implications of financialized coordination. Lead firms utilize particular coordination mechanisms in managing their supply chain and in so doing they develop and oversee the principles of participation of suppliers in global markets. This paper has shown that procurement has become a key mechanism for lead firms to drive financialization agendas in supply chain relations. Lead firms increasingly utilize value based management principles, or formalistic metric based calculations in procurement processes as a mechanism for vetting or selecting between suppliers of goods and services. The universal language of value based management is imposed by corporate offices and leads to a rupture in relations with local suppliers, enabling lead firms to elevate cost based calculations in procurement. Financialization has therefore driven lead firms to adopt 'hands-off' forms of coordination of supply chains through a global approach to sourcing, which has prioritized standards or conventions, such as value based management and cost based calculations, resulting in ruptures in deeper and 
longer term relations with local suppliers and the dis-embedding of lead firms from local territories.

The mining industry has particular characteristics which limit the generalizability of the findings of this case to other industry sectors. Mining is a highly capital intensive and therefore intensely financialized industry rendering global mining firms particularly vulnerable to the proclivities of international financial markets. At the same time, the landed nature of extractive industries creates a strong connection between lead firms and territory, particularly in boom times in which rapid extraction of large volumes of resources becomes a primary driver of firm strategy. These characteristics of mining create a tension between the de-territorialization tendencies of global financial markets and the localization pressures associated with rapid resource extraction which vary across the boom bust cycle. Other industry sectors may reveal a more stable pattern of lead firm coordination of supply chains and its associated territorial implications in the context of financialization.

This suggests opportunities for economic geographers to explore cross-sectoral variation in the effects of financialization on the territorial dimensions of lead firm coordination of global supply chains. For example, lead firms face different localization pressures in different industry sectors which include the imperative to organise and integrate global knowledge sources as evidenced by Big Pharma who have become embedded in global centres of excellence in biotechnology (Malecki 2010). The global search for talent and knowledge might operate as a localizing force against the de-territorializing effects of financialization. Cross-sectoral variations in these tensions might affect lead firm coordination of supply chains, including differences in procurement arrangements, and thereby the mechanisms through which financialization and de-territorialization unravel in particular contexts. 


\section{References}

Amin, A., and Thrift, N. 1994. Globalization, institutions, and regional development in Europe. Oxford: Oxford University Press.

Arias, M., Atienza, M., and Cademartori, J. 2014. Large mining enterprises and regional development in Chile: Between the enclave and cluster. Journal of Economic Geography:73-95.

Arrighi, G. 1994. The long twentieth century: Money, power and the origins of our times.

New York: Verso.

Austmine 2013. METS sector analysis, 2013 survey. Tribe research report. http://www.austmine.com.au/ (accessed 4 May 2013).

Australian Stock Exchange (ASX) 2013. Metals and mining fact sheet. http://www.asx.com.au/documents/resources/asx_metals_and_mining.pdf. (accessed 29 November 2014).

Baud, D., and Durand, C. 2012. Financialization, globalization and the making of profits by leading retailers. Socioeconomic Review 10:241-266.

Bridge, G. 2004. Mapping the bonanza: Geographies of mining investment in an era of neoliberal reform. The Professional Geographer 56(3):406-421.

Bridge, G. 2009. Global production networks and the extractive sector: Governing resource based development. Journal of Economic Geography 8:389-419.

Coe, N., Lai, K., and Wójcik, D. 2014. Integrating finance into global production networks. Regional Studies 48(5):761-777. 
Coe, N. M., and Yeung, H. W. D. 2015. Global production networks: Theorizing economic development in an interconnected world. Oxford: Oxford University Press.

Corbin J., and Strauss, A. 1990. Basics of qualitative research: Grounded theory procedures and techniques. London: Sage.

Cushen, J., and Thompson, P. 2016. Financialization and value: Why labour and the labour process still matters. Work, Employment and Society 30 (2): 352-65.

Ernst, D., and Kim, L. 2002. Global production networks, knowledge diffusion, and local capability formation. Resources Policy 31(8-9):1417;1429.

Foster, J., and McChesney, R. 2012. The endless crisis: How monopoly-finance capital produces stagnation and upheaval from the USA to China. Monthly Review Press.

Froud, J., Haslam, C., Johal, S., and Williams, K. 2000. Shareholder value and financialization: Consultancy promises, management moves. Economy and Society 29(1):80-110.

Galligan, B. 1989. Utah and Queensland coal. Brisbane: University of Queensland Press.

Geological Survey of Queensland 2016. Queensland's mining and petroleum industry. Department of Natural Resources and Mines. https://www.dnrm.qld.gov.au/_data/assets/pdf_file/0004/238072/queensland-miningpetroleum-overview.pdf (accessed 3 October 2016).

Gereffi, G., Humphrey, J., and Sturgeon, T. 2005. The governance of global value chains. Review of International Political Economy 12(1):78-104. 
Gibbon, P. 2002. At the cutting edge? Financialization and UK clothing retailers' global sourcing patterns and practices. Competition and Change 6:289-308.

Gibbon, P., Bair, J., and Ponte, S. 2008. Governing global value chains: An introduction. Economy and Society 37(3):315-338.

Glaser, B. G., and Strauss, A. 1967. The discovery of grounded theory: Strategies for qualitative research. London: Weidenfeld and Nicolson.

Glasgow, W. 2013. Coal outlook 'grim' but soft dollar a bonus. Australian Financial Review, 2 July 2013.

Hobbs, M. 2013. A year of action for mining sector. Australian Financial Review, 1 July 2013.

Henderson J., Dicken P., Hess M., Coe N., and Yeung, H. 2002. Global production networks and the analysis of economic development. Review of International Political Economy 9:436-464.

Hess, M. 2004. "Spatial” relationships? Towards a reconceptualization of embeddedness. Progress in Human Geography 28:165-186.

Humphrey, J., and Schmitz, H. 2002. How does insertion in global value chains affect upgrading in industrial clusters? Regional Studies 36(9):1017-1027.

Kaplinsky, R. 2004. Sustaining income growth in a globalising world: The search for the nth rent. Brighton: Centre for Research in Innovation Management, University of Brighton.

Krippner, G. R. 2005. The financialization of the American economy. Socio-Economic Review 3(2):173-208. 
Lazonick, W., and Mazzucato, M. 2013. The risk-reward nexus in the innovation-inequality relationship: Who takes the risks, who gets the rewards? Industrial and Corporate Change 22(4):1093-1128.

Lazonick, W., and O’Sullivan, M. 2000. Maximising shareholder value: A new ideology for corporate governance. Economy \& Society 29(1):13-35.

Malecki, e. J. 2010. Global knowledge and creativity: new challenges for firms and regions. Regional Studies 44.8 (2010): 1033-1052.

Mahutga, M. 2014. Global models of networked organisation, the positional power of nations and economic development. Review of International Political Economy 21(1):157-194.

Marcus, J. 2000. BHP - The quiet giant: A natural resources company in transition. Engineering and Mining Journal 2000(2):16B-16H.

Martin, J. D., and Petty, J. W. (eds) 2001. Value based management: The corporate response to the shareholder revolution. Oxford: Oxford University Press.

Macdonald-Smith, A. 2014. BHP aiming higher for projects. Australian Financial Review, 19 February 2014.

Milberg, W. 2009. Shifting sources and uses of profits: Sustaining US financialization with global value chains. Economy and Society:420-451.

Milberg, W., and Winkler, D. 2013. Outsourcing economics: Global value chains in capitalist development. Cambridge: Cambridge University Press.

Montalban, M., and Sakinç, M. E. 2013. Financialization and productive models in the pharmaceutical industry. Industrial and Corporate Change 22(4):981-1030. 
Morris, M., Kaplinsky, R., and Kaplan, D. 2012. One thing leads to another - commodities, linkages and industrial development. Resources Policy 37:408-416.

Nölke, A., and Perry, J. 2007. The power of transnational private governance: Financialization and the IASB. Business and Politics 9(3):Art. 4.

Perry, J., and Nölke, A. 2006. The political economy of international accounting standards. Review of International Political Economy 13(4):559-586.

Phelps, N., Atienza, M., and Arias, M. 2015. Encore for the enclave: The changing nature of the industry enclave with illustrations from the mining industry in Chile. Economic Geography 91(2):119-146.

Ponte, S., and Gibbon, P. 2005. Quality standards, conventions and the governance of global value chains. Economy and Society 34(1):1-31.

Price Waterhouse Cooper 2011. Mine 2011; The game has changed. http://www.austmine.com.au/News/articleType/ArticleView/articleId/823/PwC-Mine-2011-The-game-has-changed-Review-of-global-trends-in-the-mining-industry (accessed 20 November 2014).

Price Waterhouse Cooper 2014. Mine 2014: Realigning expectations. http://www.pwc.com.au/industry/energy-utilities-mining/publications/minetrends.htm (accessed 20 November 2014).

Resource Information Unit Pty. Ltd 1984. Register of Australian mining 2012/13, 119-137. Subiaco, W.A.: Resource Information Unit.

Resource Information Unit Pty. Ltd 2012. Register of Australian mining 2012/13, 80-94. Subiaco, W.A.: Resource Information Unit. 
Saunders, A. 2015. BHP inches ahead of Rio in price race. Australian Financial Review, 7 September 2015.

Saunders, A. 2015. Rio eats into ore stockpiles, races for target. Australian Financial Review, 17-18 October 2015.

Sturgeon, T. 2009. From commodity chains to value chains: Interdisciplinary theory building in an age of globalisation. In Frontiers of Commodity Chain Research, ed. J. Bair, 93109. Stanford, CA: Stanford University Press.

Uzzi, B. 1997. Social structure and competition in interfirm networks: The paradox of embeddedness. Administrative Science Quarterly 42(1): 35-67.

Vitali, S., Glattfelder, H. B., and Battison S. 2011. The network of global corporate control. PLOS ONE, $6(1)$.

Williams, K. 2000. From shareholder value to present day capitalism. Economy and Society 29(1):1-12. 